\title{
NILAI-NILAI SOSIAL DALAM NOVEL TENTANG KAMU KARYA TERE LIYE KAJIAN SOSIOLOGI SASTRA
}

\author{
Novita Linda Sari, Emi Agustina, dan Bustanuddin Lubis \\ Program Studi Pendidikan Bahasa Indonesia \\ Jurusan Pendidikan Bahasa dan Seni \\ FKIP Universitas Bengkulu \\ novitalindashary@yahoo.co.id
}

\begin{abstract}
Abstrak
Tujuan penelitian ini untuk mendeskripsikan nilai-nilai sosial yang terdapat dalam Novel Tentang Kamu karya Tere Liye. Penelitian ini merupakan penelitian kualitatif dengan menggunakan pendekatan sosiologi sastra. Penelitian ini untuk mendeskripsikan nilai-nilai sosial dalam novel Tentang Kamu karya Tere Liye. Hasil pembahasan dalam penelitian ini yaitu didapatkan fakta cerita yang berkaitan dengan nilai sosialnya yakni kekerasan, memulai usaha, marketing produk, peristiwa malari (malapetaka 15 Januari), pertemanan, dan pengkhianatan. Sedangkan nilai sosial yang terdapat dalam novel Tentang Kamu karya Tere Liye antara lain: sabar, patuh, pemaaf, membantu orang lain, peduli orang lain, bekerja keras, kesetiaan, saling percaya antar teman, tolong-menolong antar teman, dan jujur.
\end{abstract}

\section{Kata kunci: Nilai sosial, tentang kamu, sosiologi sastra.}

\begin{abstract}
The purpose of this study was to describe the social values in the novel Tentang Kamu by Tere Liye. This research was a qualitative research with sociology of literature approach. This research was to describe social values in the novel Tentang Kamu by Tere Liye. The results of the discussion in this study were obtained story fact that related to their social values namely violence, starting a business, product marketing, malaria events ( January 15 disasters), friendship, and betrayal. While the social values contained in the novel Tentang Kamu by Tere Liye included: patience, obedience, forgiveness, helping others, caring for others, working hard, loyalty, mutual trust between friends, help between friends, and honestly.
\end{abstract}

Keywords: Social values, tentang kamu, sociology of literature.

\section{PENDAHULUAN}

Karya sastra merupakan wujud gagasan seseorang melalui pandangan terhadap lingkungan sosial yang berada di sekelilingnya dengan menggunakan bahasa yang indah. Sastra hadir sebagai perenungan pengarang terhadap fenomena yang ada. Karya sastra umumnya berisi tentang permasalahan yang berada di sekitar pengarang. Permasalahan tersebut bisa saja permasalahan yang dihadapi oleh pengarang ataupun permasalahan yang dihadapi oleh orang lain yang diangkat pengarang menjadi sebuah karya sastra. 
Salah satu karya sastra yang diangkat pengarang menjadi sebuah cerita adalah novel.

Nurgiyantoro (2013:9) menyatakan bahwa novel adalah karya sastra yang mengungkapkan aspek-aspek kemanusiaan yang lebih mendalam dan disajikan dengan halus. Novel merupakan salah satu karya sastra yang berisi berbagai peristiwa yang dialami oleh tokoh secara sistematik dengan menampilkan unsur cerita yang paling lengkap.

Dalam penelitian ini, penulis membahas mengenai nilai-nilai sosial yang terdapat dalam novel Tentang Kamu karya Tere Liye. Salah satu novel yang menggambarkan nilai sosial adalah novel yang dipilih oleh peneliti yaitu novel Tentang Kamu karya Tere Liye. Novel Tentang Kamu karya Tere Liye menggambarkan sikap sosial yang diperlihatkan oleh tokoh utama yakni Sri Ningsih. Salah satu sikap sosial yang dimiliki oleh Sri Ningsih ini yaitu peduli terhadap orang lain. Ini dapat dilihat dari cuplikan peristiwa yang ada dalam novel yakni pada saat Sri Ningsih memberikan makan kepada orang yang membutuhkan. Saat itu, Sri Ningsih tengah menjual nasi goreng dengan gerobak dorongnya. Suatu hari, aku berdiri di depan gerobaknya, lapar sekali. Ibu Sri melambaikan tangan, menyuruhku mendekat. Dia memberikan satu porsi penuh nasi goreng. Sejak hari itu, aku tinggal bersamanya di Pasar Senen, belajar sekaligus bekerja dengannya. Hal itulah yang menjadi alasan penulis untuk memilih nilai sosial sebagai aspek yang perlu dikaji, sebab dalam novel ini menjelaskan mengenai nilai-nilai tersebut baik yang tersirat maupun yang tersurat.

Novel ini juga mengajarkan pentingnya arti sebuah kejujuran walaupun dalam kondisi apapun. Seperti yang dilakukan Sri saat ia harus memilih antara persahabatan atau sebuah kejujuran, jelas la memilih kejujuran walaupun itu akan membuat dirinya dibenci sahabatnya sendiri. Dari cuplikan di atas dapat kita lihat bahwa di dalam novel ini tokoh Sri Ningsih menjunjung tinggi sebuah kebenaran dan kejujuran. Tidak seperti masa sekarang ini, semua orang selalu bersembunyi dibalik kesalahan yang ia buat. Tidak ada yang berani mengatakan kebenaran, walaupun itu menyakitkan. Tokoh seperti Sri Ningsih ini sangat dicari-cari, karena sebetulnya sekarang kita sangat kekurangan orang yang memiliki sikap seperti dirinya.

Berdasarkan alasan tersebut, penulis merumuskan pemasalahan (1) Bagaimana Fakta cerita dalam novel Tentang Kamu karya Tere Liye? Dan (2) Bagaimana nilai-nilai sosial dalam novel Tentang Kamu karya Tere Liye?. Tujuan dalam penelitian ini adalah mendeskripsikan fakta cerita yang berkaitan dengan nilai sosial dalam novel Tentang Kamu karya Tere Liye. (2). Mendeskripsikan nilai-nilai sosial yang terdapat dalam novel Tentang Kamu karya Tere Liye. Dalam melakukan penelitian, penulis menggunakan teori sosiologi sastra. menurut (Damono,1978:2) mengungkapkan bahwa pendekatan terhadap sastra yang mempertimbangkan segi-segi kemasyarakatan ini oleh beberapa penulis disebut sosiologi sastra. Dalam pandangan (Faruk, 1994:4) sosiologi sastra merupakan disiplin yang tanpa bentuk, tidak terdefinisikan dengan baik, terdiri dari sejumlah studi-studi empiris dan berbagai percobaan teori agak lebih general yang masing-masingnya hanya mempunyai kesamaan dalam hal berhubungan dengan masyarakat.

Rene wellek dan Austin Warren (1993: 111) membagi telaah sosiologi sastra menjadi tiga klasifikasi, yaitu:

1. Sosiologi pengarang, profesi pengarang, dan intuisi sastra, maslah yang berkaitan di sini adalah dasar ekonomi produksi sastra, latar belakang status sosial pengarang, 
dan ideologi pengarang yang terlibat dari berbagai kegiatan pengarang di luar karya sastra. Pengarang adalah warga masyarakat, ia dapat dipelajari sebagai makhluk sosial.

2. Sosiologi karya sastra yang mempermasalahkan karya sastra itu sendiri dan yang berkaitan dengan masalah sosial, yang menjadi pokok penelahaannya atau apa yang tersirat dalam karya sastra dan apa yang menjadi tujuannya. Pendekatan yang umun dilakukan sosiologi ini mempelajari sastra sebagai dokumen sosial.

3. Sosiologi pembaca dan dampak sosial karya sastra. Pengarang dipengaruhi dan mempengaruhi masyarakat, seni tidak hanya meniru kehidupan tapi juga membentuknya.

\section{METODE}

Penelitian ini menggunakan metode kualitatif. Menurut Bogdan dan Taylor dalam (Moleong, 2014 : 4) mendefinisikan metode kualitatif sebagai prosedur penelitian yang menghasilkan data deskriptif berupa kata-kata tertulis atau lisan dari orang-orang dan perilaku yang diamati. Sumber data dalam penelitian ini adalah novel Tentang Kamu karya Tere Liye yang diterbitkan oleh Republika pada oktober 2016 kemarin dengan jumlah 524 halaman. Data dalam penelitian ini adalah kalimat-kalimat ataupun ujaran-ujaran yang mengandung nilai-nilai sosial.

Teknik pengumpulan data dalam penelitian ini adalah teknik studi pustaka. Studi pustaka dilakukan untuk mendapatkan bahan-bahan dan informasi yang berhubungan dengan penelitian seperti buku-buku, artikel, dokumendokumen lain yang berhubungan dengan penelitian. Langkah-langkah analisis data yang digunakan dalam penelitian ini yaitu: (1) Membaca dan memahami novel Tentang Kamu karya Tere Liye. (2)
Membuat sinopsis cerita dari novel Tentang Kamu karya Tere Liye. (3) Mendeskripsikan fakta cerita yang berkaitan dengan nilai sosial yang terdapat dalam novel Tentang Kamu karya Tere Liye. (4) Mengidentifikasikan nilai-nilai sosial yang terdapat dalam novel Tentang Kamu karya Tere Liye. (5) Menganalisis nilai-nilai sosial yang teridentifikasi di dalam novel Tentang kamu karya Tere Liye. (6) Membuat kesimpulan.

\section{HASIL DAN PEMBAHASAN}

Peristiwa di dalam novel Tentang Kamu karya Tere Liye telah ditemukan oleh penulis fakta-fakta cerita yang berkaitan dengan nilai sosial yakni sebagai berikut.

\section{Peristiwa kekerasan}

Peristiwa kekerasan yang terdapat dalam novel Tentang Kamu karya Tere Liye ini terlihat pada tokoh Sri Ningsih. Pada tokoh Sri Ningsih terlihat dalam novel bahwa ia sebagai anak tiri dari Nusi Maratta mengalami kekerasan. Kekerasaan yang dialami Sri Ningsih yakni kekerasan fisik dan psikis. Kekerasan fisik yang terlihat yakni Nusi Martta sebagai Ibu tirinya sering kali memukul Sri Ningsih dengan menggunakan rotan. Sedangkan kekerasan psikis yang dialami Sri Ningsih yakni saat ia dipanggil oleh Ibu tirinya sebagai anak sial! Anak yang dikutuk. Seperti terlihat dalam kutipan.

"berapa kali harus kubilang, hah? Nusi Maratta berteriak, wajahnya merah padam.

Maaf, Bu. Aku tidak sengaja. Sri gemetar ketakutan.

Matamu taruh dimana? Nusi Maratta meraih rotan panjang di atas meja.

Sri hendak melangkah mundur, tapi kakinya seperti berat digerakkan.

Kamu kira harga bahan makanan murah? Gratis?

Nusi memukulkan rotan, menghantam telak lengan Sri.

Gadis kecil itu mengaduh perlahan. Satu kali. Dua kali. Tiga kali. 
Pel seluruh lantai, atau malam ini kamu tidur di luar! Tidak ada makan malam untukmu. Nusi menyalak beringas, setelah puas memukul anak tirinya." (Liye, 2016:103-104) "kamu tahu kenapa bapakmu tenggelam di laut, hah? Tahu tidak?

Sri tidak menjawab

Itu karena kamu, anak sial! Anak yang dikutuk.

Ibumu! Masih ingat ibumu? Dia mati saat melahirkan anaknya yang dikutuk. Dan setelah itu? Bapakmu mati hanya karena ingin membelikan sepatu baru untukmu. Kamu membawa seluruh kesialan keluarga ini. Kamu membuat orang lain mati." (Liye, 2016:104-105).

Kutipan di atas menjelaskan bahwa tokoh Sri Ningsih mengalami kekerasan fisik dan psikis oleh ibu tirinya.

\section{Peristiwa memulai usaha}

Peristiwa memulai usaha dalam novel Tentang Kamu karya Tere Liye diperlihatkan bahwa tokoh Sri Ningsih memulai usaha. Sri yang hanya tamat dari sekolah madrasah memiliki kecerdasan dan ketertarikan dalam usaha berdagang dan berbisnis. Pada saat menjadi seorang pedagang, dagangannya berkembang, sehingga ia menambah jumlah karyawan serta menambah jumlah gerobak dorong yang ia miliki. Sri memahami bahwa sebagai seorang pedagang, hal yang harus dimiliki adalah sifat kreatif, agar dalam berdagang kita tidak mundur dan tetap berada paling depan. Namun, bisnis dagangannya harus hancur hanya karena banyak orang yang meniru gerobak dorong yang ia buat dan ketidakjujuran pekerja Sri. Seperti terlihat dalam kutipan berikut.

"Aku sekarang punya dua puluh gerobak dorong, mulai dari menjual nasi goreng, bakso, mie ayam, hingga mencoba berjualan sayur keliling dengan gerobak. Aku sudah membeli rumah kontrakanku, juga rumah di sebelahnya. Bisnis jualan dengan gerobak dorong semakin maju setahun terakhir. Tapi masalahnya juga semakin banyak.
Masalah pertama adalah, pedagang lain telah membuat gerobak yang sama, mereka meniru. Dulu baru satu-dua, tapi sekarang dimana-mana. Berjualan dengan gerobak tidak aneh lagi. Keuntungan menurun drastis. Apalagi jika besok lusa tambah banyak yang meniru, mungkin berdagang dengan gerobak dorong tidak lagi menarik. Masalah kedua, tidak semua orang yang bekerja padaku dapat dipercaya. Mingguminggu ini saja sudah dua kali terjadi, uang penjualan dibawa kabur oleh pedagangmasih untung gerobaknya bisa ditemukan. Aku ikhlas soal uangnya, karena besok lusa uang bisa dicari, tapi itu membuatku kecewa, memikirkan banyak hal. Kenapa orang mudah sekali menghianati? Bukankah dalam hidup ini kejujuran adalah hal penting? Sepertinya aku harus mulai membiasakan diri menghadapi masalah seperti ini.

Masalah ketiga, razia petugas. Dulu, ketika barang dagangan dipikul atau digendong, tidak terlalu sulit untuk menghindari razia. Tapi dengan gerobak, itu jadi rumit. Belum lagi petugas semakin sering merazia pedagang kaki lima. Enam bulan ini, aku harus mengurus empat gerobak yang ditahan petugas. Ada banyak kawasan yang terlarang untuk berjualan sekarang, kami dianggap mengganggu keindahan kota. " (Liye, 2016: 238-239).

Kutipan di atas memperlihatkan kepada kita bagaimana tokoh Sri Ningsih menghadapi setiap permasalahan saat memulai suatu usaha. Permasalahan demi permasalahan datang menghampiri Sri Ningsih, dan dengan lapang hati ia menerima semuanya.

\section{Marketing Produk}

Peristiwa tersebut terlihat saat Sri Ningsih memiliki sebuah pabrik sabun mandi. Setelah meninggalkan usaha dagang, Sri Ningsih beralih membuka pabrik sendiri. Pabrik yang ia bangun mulanya belum berkembang, namun karena kegigihan Sri Ningsih memasarkan produk sabun mandi yang ia produksi, akhirnya 
yang kemarin menolak menjual, kini meletakkan di rak bagian depan. Seperti terlihat dalam kutipan

"Aku tidak punya uang untuk memasang iklan di koran, terlalu mahal, tapi aku bisa mencetak puluhan ribu selebaran promosi. Setiap hari, dibantu dua staf, kami menyebar selebaran. Acara-acara besar, keramaian, pesta rakyat, bahkan jika hanya ada kabar arisan di sebuah tempat, kami meluncur ke sana untuk promosi. Aku ingin saat produksi pertama keluar, sabun mandi itu langsung terjual. Membuat produk itu perkara gampang, siapa pun bisa melakukannya, tapi menjualnya, itu baru istimewa. Aku menanamkan daya juang itu kepada stafku, melatih mereka tahan banting, dengan berkali-kali bilang, 'bayangkan besok lusa di setiap rumah-rumah, akan ada sabun produksi kita.'

Kerja keras tidak pernah mengkhianati hasil, Nur. Tiga bulan sejak rilis pertamanya, sabun 'Rahayu' laris manis. Toko-toko yang dulu menolak menjualnya, sekarang mengirim pesanan. Supermarket, pusat perbelanjaan yang dulu enggan mendisplay produk itu, sekarang meletakkannya di rak terdepan. Aku sekarang sibuk memikirkan menambah kapasitas pabrik, karena produksi sabun bekejaran dengan omzet penjualan."(Liye, 2016:262)

Kutipan di atas memperlihatkan kepada kita semua bahwa setiap usaha yang kita lakukan akan mendapatkan balasan. Semakin banyak usaha yang kita lakukan, maka semakin baik pula hasil yang akan kita dapatkan.

\section{Peristiwa Malari (Malapetaka 15 Januari)}

Peristiwa Malari merupakan peristiwa kerusuhan sosial yang terjadi pada tahun 1974 yang dilakukan oleh ribuan mahasiswa Indonesia. Atas kejadian tersebut, bisnis yang dimiliki oleh Sri Ningsih hancur. Sebelum terjadi peristiwa besar tersebut, Sri Ningsih memiliki bisnis sewa mobil. Bisnisnya berkembang. Waktu itu, Sri Ningsih memang menggunakan mobil jepang, la memilih mobil jepang tersebut dikarenakan mobil Jepang mudah dalam perawatan dan juga hemat bensin. Seperti kutipan berikut.

"Aku resmi memulai usaha baru, sewa mobil. Namanya "Rahayu Car Rental", aku sengaja memakai bahasa asing, karena target pasarnya mereka. Aku juga sengaja memilih mobil jepang, karena walaupun taksi lain lebih banyak menggunakan mobil merk Amerika, mobil jepang lebih hemat bensin, lebih mudah perawatan. Besok lusa merk ini akan mengalahkan merk amerika." (Liye,2016:244)

"ini.... Ini sangat menyakitkan. Seluruh usaha yang dimulai dari gerobak nasi goreng, hancur dalam sehari. Benar-benar hancur, hanya menyisakan pakaian yang aku kenakan. Aku tidak punya tempat tinggal, aku kehilangan kantor, rumah, bisnisku. Aku sekarang menumpang di Pulogadung. Aku sudah seminggu disini, dua hari lalu aku melihat langsung puing-puing toko. Membuatku menangis.aku sudah berusaha menemui perusahaan asuransi mobil, mereka tidak bersedia menanggung ganti rugi kerusakan, karena peristiwa hura-hara tidak termasuk klausul yang ditanggung. "(Liye, 2016:250)

Berdasarkan kutipan di atas, dijelaskan bahwa tokoh Sri Ningsih merupakan orang yang merasakan kerugian atas peristiwa tersebut. Atas peristiwa tersebut, usaha bisnis sewa mobilnya hancur.

\section{Pertemanan}

Peristiwa pertemananterlihat antara Sri Ningsih dengan tokoh lain, yaitu Nur'aini, Sulastri, dan Lucy. Ketiga tokoh ini memperlihatkan sikap sosial yang dimiliki oleh tokoh Sri Ningsih. Seperti dalam kutipan.

"apa kabar, Nur? Semoga kamu, suamimu Mas Arifin, teman-teman, guru, dan muridmurid di madrasah senantiasa sehat walafiat. 
Aku sudah tiba di Jakarta dua minggu lalu. Maaf jika terlambat sekali mengirim surat. Tempat baru, semua serba baru, aku masih menyesuaikan diri, termasuk mencari di mana kantor pos terdekat. Tapi bukan itu alasannya, Nur. Aku tidak bisa mengirim surat segera karena malu tidak banyak yang bisa diceritakan, aku tidak mau membuat kamu cemas" (Liye, 2016 :215)

"boleh aku bertanya sesuatu, Lucy?

Lucy mengangguk. Mereka berdua tengah berada di bengkel, mengawasi bus-bus yang sedang diperbaiki. Itu salah satu tugas Lucy, Sri menemaninya setelah menyikat semua bus.

Apakah kamu tahu daerah yang sewa apartemennya murah?

Di apartemenku murah, Sri. Mau pindah ke tempatku?

Sri menggeleng. Dia tahu daerah tempat Lucy tinggal, $80 \%$ penghuninya pendatang polandia, dia akan kesulitan berbaur disanadan lebih penting lagi kesulitan mencari makanan.

Aku mencari tempat yang punya restoran halal.

Kalau begitu, kamu bisa mencoba kawasan little India, Sri. Lucy memberi ide. " (Liye, 2016:319-320).

Berdasarkan kutipan di atas, dijelaskan bahwa tokoh Sri Ninngsih menjalin pertemanan yang baik dengan tokoh lain, seperti Lucy dan Nur'aini. Mereka tidak memiliki konflik satu sama lainnya. Mereka berteman dengan baik.

\section{Pengkhianatan}

Peristiwa pengkhianatan terlihat saat tokoh tokoh Sri Ningsih menjadi saksi dalam persidangan atas kasus pembunuhan keluarga Ki'ai Ma'sum yang dilakukan oleh Sulastri dan Musoh. Sri yang merupakan sahabat Sulastri memang mengetahui niat jahat Sulastri, berusaha menolong keluarga Ki'ai Ma'sum. Di sana terlihat bahwa tokoh Sri Ningsih mengkhianati persahabatannya dengan Sulastri atas alasan kejujuran. Seperti terlihat dalam kutipan berikut. "pengadilan memutuskan menghadirkan Sri Ningsih sebagai saksi.

Saat hakim bertanya, apakah Sulastri terlibat dalam pembunuhan Ki'ai Ma'sum, Sri terdiam lama.

Sri menatap wajah Mbak Lastri.

Sri menangis. Apakah dia akan bicara kebenaran? Atau dia akan memilih persahabatan?

Saudara saksi. Harap jawab pertanyaannya. Sri menyeka pipinya.

Baginya, hinggga kapan pun, mbak lastri adalah sahabat terbaiknya. Terlepas dari pilihan politik, rasa dengki, apapun itu, Mbak Lastri adalah sahabatnya. Tapi Sri tidak pernah berbohong dalam hidupnya, dan dia tidak akan tergoda untuk mulai berbohong. Maafkan aku, Mbak Lastri, Sri terisak, maafkan aku jika 'mengkhianatimu'dalam pengadilan ini.

Sri mengangguk.

Hakim mengetuk palunya. (Liye, 2016:199).

Kutipan di atas menjelaskan bahwa tokoh Sri Ningsih berkhianat kepada shabatnya sendiri, Sulastri. Berkhianat disini untuk kebaikan bukan dalam hal yang negatif. la menjunjung tinggi kejujuran di atas pertemanannya.

Menurut Zubaedi (dalam Purwanti, 2016: 47) menyebutkan bahwa nilai sosial terdiri atas beberapa sub nilai, diantaranya ialah Kasih Sayang (Loves), yang terdiri atas Pengabdian, Tolong-Menolong, Kekeluargaan, Kesetiaan dan Kepedulian. Tanggung Jawab (Responsibility) yang terdiri atas, Nilai Rasa Memiliki, dan Empati, dan Keserasian Hidup (life Harmony) yang terdiriatasToleransi, Kerjasama, dan Musyawarah. Namun, setelah penulis melakukan penelitian di dalam novel Tentang Kamu karya Tere Liye maka di dapatkan nilai-nilai sosial sebagai berikut.

\section{Sabar}

Sabar merupakan suatu sikap menahan emosi dan keinginan, serta bertahan dalam situasi sulit dengan tidak mengeluh. Sikap 
tersebut merupakan salah satu contoh nilai sosial yang bersifat positif. Sri Ningsih sabar menahan atas apa yang telah terjadi padanya. la menahan semua kekejaman yang telah dilakukan oleh ibu tirinya. la juga menahan kelaparan selama satu hari satu malam. Namun, la tetap berbesar hati menerima kenyataan tersebut. Berdamai dengan semua masalah yang ia hadapi. Seperti terlihat dalam kutipan berikut.

"Sri meremas jemarinya. Matanya basah.

Dia lapar sekali. Apalagi setelah berjuang mengambil air bersih di seberang. Tidakkah ibu tirinya sedikit saja mau mengasihaninya? Tidakkah ibunya sekali saja mau peduli padanya? Sri menggigit bibir, segera mengusir pikiran jelek yang melintas di kepalanya. Tidak apa, tidak apa... sri menunduk membujuk hatinya, setidaknya tilamuta mala mini tidur dengan perut kenyang. Itu lebih dari cukup. Dulu bapaknya berpesan, selain selalu patuh pada ibunya, agar dia menjaga Tilamuta." (Liye, 2016:122-123)

doakan aku kuat melewati semuanya, Nur. Malam ini, menulis surat ini sambil menangis, hatiku terasa lebih ringan. Besok, aku berjanji akan memulainya dari awal "(Liye,2016:249-250)

Dua kutipan di atas menjelaskan bahwa Sri Ningsih selalu sabar menghadapi setiap permasalahan yang dialaminya. Pertama, kekejaman ibu tirinya, ia selalu sabar atas apa yang telah dilakukan ibu tirinya. Kedua, ia berusaha sabar terhadap bisnis sewa mobilnya hancur atas kerusuhan sosial yang terjadi pada tahun 1974 atau sering dikenal dengan Peristiwa Malari(Malapetaka 15 Januari).

\section{Patuh}

Patuhmerupakan suatu sikap sopan yang biasanya ditujukan pada orang yang lebih tua. Di dalam novel terlihat pada tokoh Sri Ningsih yang selalu patuh terhadap perintah dari ibu tirinya. Sikap yang dimiliki oleh Sri Ningsih termasuk nilai sosial yang positif, dimana sebagai anak sudah seharusnya kita tidak melawan/ membantah perintah orang tua. Seperti realita sekarang ini, banyak sekali anakanak yang sering membantah orang tuanya sendiri. Seperti pada kutipan berikut.

" kamu ambil air bersih di seberang pulau sekarang juga! Aku tidak mau tahu. Nusi Maratta meraih jeriken kosong, melemparkannya ke rah Sri, 'dan Tilamutta masuk kamar! Apa pula yang kamu lakukan di dapur bersama anak yang dikutuk ini!' Tilamutta berlarian meninggalkan dapur. Meninggalkan Sri yang mengigit bibir. Bergegas, Sri!!! Kamu menunggu apa lagi? Nusi meraih tongkat rotan, mengancam.

Tidak ada pilihan bagi Sri, dia harus melaksanakan perintah ibu tirinya, dia meraih jeriken." (Liye, 2016:118)

Kutipan di atas memperlihatkan bahwa kepatuhan yang dimiliki oleh Sri Ningsih terhadap ibu tirinya. la selalu melaksanakan perintah yang diucapkan oleh ibu tirinya. Tidak pernah sekalipun Sri mencoba untuk menjawab tidak. Sikap yang dimiliki oleh Sri Ningsih termasuk nilai sosial yang positif, dimana sebagai anak sudah seharusnya kita tidak melawan/ membantah perintah orang tua.

\section{Pemaaf}

Merupakan salah satu nilai sosial. Pemaaf berarti orang yang rela memberi maaf kepada orang lain. Sikap pemaaf berarti sikap suka memaafkan kesalahan orang lain tanpa sedikit pun ada rasa benci dan keinginan untuk membalasnya. Sikap pemaaf disini terlihat saat Sri Ningsih menyelamatkan Ibu tiri beserta adik tirinya ketika kebakaran yang terjadi di rumahnya. Sri Ningsih memiliki sikap pemaaf. Tidak terlintas sedikitpun dihatinya untuk membalas 
perlakuan kasar ibu tirinya itu. seperti

terlihat dalam kutipan berikut.

"ayo, Ibu! Ikut aku!

Selamatkan adikmu, Sri. Suara Nusi Maratta bergetar.

Sri menatap wajah ibu tirinya. Setelah sekian lama, sore itu, Nusi Maratta untuk pertama kalinya bisa menatap secara utuh wajah Sri. Menyaksikan dengan akurat ekspresi wajah Sri yang selama ini lebih banyak menunduk. Lihatlah, tidak ada kebencian di mata Sri, tidak ada dendam kesumat meski dia diperlakukan buruk lima tahun terakhir. Anak tirinya justru mengulurkan tangan, amat tulus menolongnya" (Liye, 2016:136).

Kutipan di atas menjelaskan bahwa tokoh Sri Ningsih memiliki sikap pemaaf. Tidak terlintas sedikitpun dihatinya untuk membalas perlakuan kasar ibu tirinya itu. padahal jika ia mau, mudah saja. Tetapi karena tokoh Sri Ningsih memiliki sikap sosial yang tinggi, ia melupakan semua kesakitan yang ia alami tersebut.

\section{Membantu orang lain}

Sikap saling membantu antar sesama manusia sangat baik jika diterapkan. Sebab kita tahu bahwa manusia merupakan mahkluk sosial yang memerlukan bantuan orang lain. Seperti yang dilakukan oleh tokoh Sri Ningsih yang membantu orang lain. Salah satunya memberikan pekerjaan. Sri Ningsih memiliki sikap sosial. la memberikan pekerjaan terhadap orang lain. la begitu dikarenakan ia pernah merasakan hal yang serupa. Saat ia tinggal di Jakarta selama enam minggu tidak memiliki pekerjaan. Sri yang berjiwa sosial tinggi itu mencoba memberikan pekerjaan bagi orang yang membutuhkannya. Seperti terlihat dalam kutipan novel berikut.

"sekarang aku bangun lebih pagi, Nur, pukul dua sudah berangkat ke pasar, membeli bahan-bahan, menyiapkan dagangan. Dengan dua gerobak baru, lebih banyak uang yang bisa kutabung setiap hari. Rencanaku sekarang semakin banyak. Aku belum pernah sesemangat ini, Nur. Aku mengajak anak-anak tetangga untuk ikut bekerja, membantu di dapur, juga mendorong gerobak berjualan. Seru sekali bisa memberikan pekerjaan kepada orang lain, apalagi mengingat dulu setiba di Jakarta aku harus mati-matian mencarinya. Semoga semua berjalan lancar." (Liye, 2016:234235)

Kutipan di atas menjelaskan bahwa tokoh Sri Ningsih memiliki sikap sosial. la memberikan pekerjaan terhadap orang lain.

\section{Peduli terhadap orang lain}

Sikap peduli terhadap orang lain dalam novel ini terlihat saat Sri Ningsih membantu dan memberi makan kepada anak kecil yang tengah berdiri di depan jualannya. Sri Ningsih memiliki sikap peduli sosial yang tinggi. la tidak peduli siapa yang ditolongnya itu. ia tidak melihat asal usul anak tersebut. Dia begitu saja percaya dan mau mendidik anak tersebut layaknya anak sendiri. Seperti dalam kutipan novel berikut.

"aku memang bukan siapa-siapa bagi ibu Sri Ningsih, hanya remaja yang dipungut dari jalanan, tapi bagiku dia adalah malaikat. Dia memberiku makan saat aku kelaparan, mendidikku, memberikan kesempatan. Empat puluh tahun lamanya aku bekerja di pabrik ini, mengenal setiap jengkalnya. Bagiku lbu Sri adalah segalanya, dan dia pergi begitu saja tanpa pamit. Aku ingin sekali tahu, ke mana dia setelah itu? agar aku bisa menemuinya, memeluknya erat, mencium tangannya, berterima kasih atas segalanya. Kalimat Chaterine terhenti, suaranya tercekat."(Liye, 2016:277)

Pada kutipan di atas, dapat dijelaskan bahwa tokoh Sri Ningsih memiliki sikap 
peduli sosial yang tinggi. la tidak peduli siapa yang ditolongnya itu. ia tidak melihat asal usul anak tersebut. Dia begitu saja percaya dan mau mendidik anak tersebut layaknya anak sendiri.

\section{Bekerja keras}

Bekerja keras merupakan sikap yang selalu pantang menyerah dalam melakukan sesuatu. Sikap tersebut sangat baik jika tertanam dalam diri seseorang untuk kita terapkan dalam kehidupan bermasyarakat. Sri Ningsih selalu yakin terhadap pengorbanan yang ia lakukan akan terbayarkan. Dia selalu yakin bahwa apa yang ia lakukan akan mendapatkan balasan apa yang telah kita korbankan dan perjuangkan. Seperti terlihat dalam kutipan berikut.

"kerja keras tidak pernah menghianati hasil, Nur. Tiga bulan sejak rilis pertamanya, sabun 'Rahayu' laris manis. Toko-toko yang dulu menolak menjualnya, sekarang mengirim pesanan. Supermarket, pusat perbelanjaan yang dulu enggan mendisplay produk itu, sekarang meletakkannya di rak terdepan. Aku sekarang sibuk memikirkan menambah kapasitas pabrik, karena produksi sabun berkejaran dengan omset penjualan."(Liye, 2016:262)

Kutipan di atas menjelaskan bahwa keyakinan Sri Ningsih terhadap pengorbanannya akan terbayarkan. Dia selalu yakin bahwa apa yang ia lakukan akan mendapatkan balasan apa yang telah kita korbankan dan perjuangkan.

\section{Kesetiaan}

Kesetiaan merupakan suatu kondisi bagaimana kita mempertahankan suatu hubungan. Dalam novel ini tertuang saat Sri Ningsih dan Nur'aini tidak berada di tempat yang sama. Walaupun begitu, Sri dan Nur'aini tetap saling memberi kabar satu sama lain lewat surat. persahabatan yang terjalin oleh Sri Ningsih dan Nur'aini tergolong kekal. Sri dan Nur'aini tetap setia satu sama lain yaitu tetap memberikan kabar satu sama lain. Walaupun mereka berada di tempat yang berjauhan, bahakn berbeda Negara sekalipun, mereka tetap setia satu sama lain. Tidak ada pengkhianatan diantara mereka satu sama lainnya. Seperti terlihat dalam kutipan berikut.

"apa kabar, Nur? Semoga kamu, suamimu mas Arifin, teman-teman, guru, dan muridmurid di madrasah senantiasa sehat walafiat.

Aku sudah tiba di Jakarta dua minggu lalu. Maaf jika terlambat sekali mengirim surat. Tempat baru, semua serba baru, aku masih menyesuaikan diri, termasuk mencari di mana kantor pos terdekat. Tapi bukan itu alasannya, Nur. Aku tidak bisa mengirim surat segera karena malu tidak banyak yang bisa diceritakan, aku tidak mau membuat kamu cemas" (Liye, 2016 :215)

Kutipan di atas menjelaskan bahwa persahabatan yang terjalin oleh Sri Ningsih dan Nur'aini tergolong kekal. Sri dan Nur'aini tetap setia satu sama lain yaitu tetap memberikan kabar satu sama lain. Walaupun mereka berada di tempat yang berjauhan, bahakn berbeda Negara sekalipun, mereka tetap setia satu sama lain. Tidak ada pengkhianatan diantara mereka satu sama lainnya.

\section{Saling percaya antar teman}

Tokoh Sri Ningsih dalam novel sangat memegang teguh sebuah kepercayaan yang dipegang. Seperti yang dilakukan Sri Ningsih terhadap Nur'aini. la sangat mempercayai sahabatnya itu untuk menyimpan surat wasiat yang ia buat demi menyelamatkan harta kekayaannya. Sri Ningsih memiliki sikap percaya terhadap sahabat nya Nur'aini. Sehingga surat wasiat yang ia buat pun diberikan kepada sahabatnya itu. seperti terlihat dalam kutipan berikut. 
"Nur, buka surat ini ketika kamu mendengar kabar kalau aku telah meninggal. Atau berikan surat ini kepada pengacara dari belgrave Square, London. Aku tidak mengenal siapa pengacara itu, tapi kamu bisa mempercayainya hidup mati. Dari sahabatmu, Sri Ningsih (Liye,2016:486)

Kutipan di atas menjelaskan bahwa tokoh Sri Ningsih memiliki sikap percaya terhadap sahabat nya Nur'aini. Sehingga surat wasiat yang ia buat pun diberikan kepada sahabatnya.

\section{Tolong-menolong antar teman}

Tolong-menolong merupakan salah satu nilai sosial positif pula. Di dalam novel terlihat saat tokoh Sri Ningsih ingin mencari sebuah kontrakan. Lucy yang merupakan teman di kantor Sri memberikan tempat penginapan murah yang bisa di tempati oleh Sri. Sesama teman mereka saling membantu satu sama lain. Jika salah satu diantara mereka dalam kesusahan. Mereka siap membantu kapanpun jika diperlukan. Seperti dalam kutipan berikut.

"Lucy memberikan daftar kawasan Little
India di London, mulai dari
Kingsbury,Hounslow, Southall, juga
termasuk tempat Sri sekarang tinggal,
Statford. Separuh lokasi itu langsung di
coret karena letaknya jauh dari tempat
kerja, separuh lagi dia kunjungi saat hari
libur, surveylangsung. "(Liye,2016:320).

Kutipan di atas menjelaskan bahwa sesama teman mereka saling membantu satu sama lain. Jika salah satu diantara mereka dalam kesusahan. Mereka siap membantu kapanpun jika diperlukan.

\section{Jujur}

Sikap jujur yang terlihat dalam novel Tentang Kamu karya Tere Liye terlihat saat tokoh Sri Ningsih menjadi sebuah saksi dalam persidangan. la ditunjuk oleh hakim sebagai saksi atas pembunuhan yang dilakukan Musoh dan Sulastri terhadap keluarga Ki'ai Ma'sum. Akhirnya Sri memilih memilih kejujuran dalam persidangan tersebut. Seperti terlihat dalam kutipan berikut.

"pengadilan memutuskan menghadirkan Sri Ningsih sebagai saksi. Saat hakim bertanya, apakah Sulastri terlibat dalam pembunuhan Ki'ai Ma'sum, Sri terdiam lama. Sri menatap wajah Mbak Lastri.Sri menangis. Apakah dia akan bicara kebenaran? Atau dia akan memilih persahabatan?Saudara saksi. Harap jawab pertanyaannya. Sri menyeka pipinya. Baginya, hinggga kapan pun, mbak lastri adalah sahabat terbaiknya. Terlepas dari pilihan politik, rasa dengki, apapun itu, Mbak Lastri adalah sahabatnya. Tapi Sri tidak pernah berbohong dalam hidupnya, dan dia tidak akan tergoda untuk mulai berbohong. Maafkan aku, Mbak Lastri, Sri terisak, maafkan aku jika 'mengkhianatimu'dalam pengadilan ini. Sri mengangguk.Hakim mengetuk palunya. (Liye, 2016:199).

Kutipan di atas menjelaskan bahwa Tokoh Sri Ningsih memilih sebuah kejujuran walaupun dirinya harus dibenci oleh sahabatnya sendiri. Sri tahu bahwa Sulastri akan membencinya. Tapi, jauh di dalam lubuk hatinya, la tetaplah Sri Ningsih sahabat Sulastri. Jika kita kaitkan dengan fenomena sekarang, bahwa sulit sekarang ini kita menemukan tokoh seperti yang dimiliki oleh Sri Ningsih. la rela dibenci oleh sahabatnya sendiri demi menegakkan kebenaran. Sekarang yang ada hanyalah orang yang sering bersembunyi, mereka bahkan rela menyuap pengacara/ bahkan melakukan apapun demi menjaga kebenaran itu akan terungkap. Sri dijelaskan memiliki jiwa sosial yang positif yakni ia meninggikan nilai kejujuran di atas nilai persahabatan.

\section{PENUTUP}

\section{Kesimpulan}

Berdasarkan hasil penelitian yang telah dilakukan oleh penulis pada novel Tentang Kamu karya Tere Liye dapat 
disimpulkan sebagai berikut. Fakta cerita di dalam novel ini adalah kekerasan, terutama kekerasan psikis, dimana tokoh Sri Ningsih sering dianggap sebagai anak sial, anak yang dikutuk oleh ibu tirinya. Keadaan seperti itu, oleh Sri Ningsih direspon dengan memaafkan semua orang yang menyakitinya, bersedia mengalah, dan menelan seluruh kepedihan yang dilakukan orang lain terhadapnya. Tetapi, bagi tokoh lain, tidak sepenuhnya seperti itu. Novel Tentang Kamu bercerita tentang Sri Ningsih yang memaafkan orang yang menyakitinya, berusaha mengalah, dan menelan setiap kepedihannya. Tetapi tokoh-tokoh lain tidak seperti itu, hanya sebagian kebaikan Sri Ningsih yang dimiliki. Sebenarnya pengarang menyarankan kepada pembaca untuk menjadi "Kamu" seperti Sri Ningsih. Seperti itulah nilai-nilai sosial yang ditawarkan oleh Tere Liye.

\section{Saran}

Setelah penulis melakukan analisis nilai sosial dalam novel Tentang Kamu karya Tere Liye ada beberapa saran yang penulis sampaikan:

1. Bagi Masyarakat

Semoga dengan adanya skripsi mengenai nilai sosial ini membuat kita semakin peduli terhadap orang lain demi mewujudkan suasana yang harmonis dalam kehidupan bermasyarakat.
2. Bagi dunia Penelitian

Di dalam novel Tentang Kamu karya Tere Liye ini banyak sekali mengkaji hal-hal yang berhubungan dengan karakter yang amat baik. Saran kepada peneliti selanjutnya untuk dapat melakukan penelitan dari berbagai aspek yang lain.

\section{DAFTAR PUSTAKA}

Damono, Sapardi Joko. 1978. Sosiologi Sastra sebuah pengantar ringkas. Jakarta: Pusat Pembinaan dan Pengembangan Bahasa.

Faruk. 1994. Pengantar Sosiologi Sastra. Yogyakarta: Pustaka Pelajar.

Liye, Tere. 2016. Tentang Kamu. Jakarta: Republika.

Moeleong, Lexy J. 2014. Metodologi penelitian kualitatif. Bandung: PT Remaja Rosda Karya.

Nurgiyantoro, Burhan. 2013. Teori Pengkajian Fiksi. Yogyakarta: Gadjah Mada University Press.

Purwanti, Lia Dewi . 2016. Nilai pendidikan sosial dalam novel tenggelamnya kapal van der wijck karya Buya Hamka. Skripsi. Institut Agama Islam Negeri Salatiga. Salatiga.

Wellek, Rene \& Warren, Austin. 1993. Teori Kesusastraan. Jakarta: PT Gramedia. 